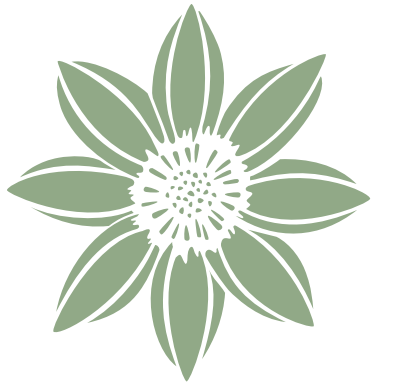

\title{
Anatomy of the sporophyte of Anemia phyllitidis var. phyllitidis (Anemiaceae) from a riparian forest (Tucumán, Argentina)
}

\section{Acta Botanica Mexicana phyllitidis (Anemiaceae) de un bosque de ribera (Tucumán, Argentina)}

\author{
Anatomía del esporofito de Anemia phyllitidis var.
}

\author{
María G. Romagnoli' (D), Marcela A. Hernández 2,3 (D), Patricia L. Albornoz1,2,3 (iD)
}

\begin{abstract}
:
Background and Aims: In Argentina seven species of the genus Anemia are recognized; one of them, A. phyllitidis, has two varieties. The anatomical records for A. phyllitidis var. phyllitidis are scarce and refer to the ontogeny of stomata, epidermis structure and type of petiole stele. This variety, which occurs in riparian forests, is affected by the increase of seasonal ecological pressures. There is scarce information about its sporophyte anatomy; hence, the aim of this work was to characterize it.

Methods: Five specimens were collected from the margin of the El Parque stream (Tucumán-Argentina). A part was herborized and the other part was fixed in FAA. Subsequently, conventional histological techniques were used and stoma density and size of stomata and trichomes were determined. Histochemical tests were performed to detect starch (lugol) and phenolic compounds (10\% ferric chloride).

Key results: Anemia phyllitidis var. phyllitidis shows diarch roots and dictyostelic rhizome covered with glandular trichomes. The petiole is covered by glandular trichomes, epidermis and subepidermis composed of lignified fibers, vascular bundle with phloem surrounding xylem, two-layered pericycle surrounded by endodermis and cortical tissue with starch and phenolic compounds. Sterile pinnae have pericytic, anomocytic, and desmocytic stomata (mean size $49.8 \mu \mathrm{m} \times 38.7 \mu \mathrm{m}$ ); glandular trichomes; dorsoventral hypostomatic lamina, vascular bundles with pericycle and endodermis. Fertile pinnae are anatomically similar to the rachis. Silica is present in some epidermal cells of the different organs.

Conclusions: The sporophyte of $A$. phyllitidis var. phyllitidis showed anatomical, morphological and physiological traits that reveal its adaptation to the riparian habitat where it grows. At the same time, the description of this variety is deepened and unpublished data for the genus are provided, such as the presence of stegmata in the fertile pinnae.
\end{abstract}

Key words: riparian forests, silica, stegmata, trichome, xeric environments.

\section{Resumen:}

Antecedentes y Objetivos: En Argentina, el género Anemia se encuentra representado por siete especies, una de ellas, A. phyllitidis, con dos variedades. Los antecedentes anatómicos para A. phyllitidis var. phyllitidis son escasos y están referidos a la ontogenia de estomas, estructura de epidermis y tipo de estela del pecíolo. Esta variedad, que habita en bosques riparios, es afectada por el incremento de presiones ecológicas estacionales. Debido a que la información que se registra acerca de la anatomía del esporofito es escasa, el objetivo de este trabajo fue caracterizarlo.

Métodos: Cinco especímenes fueron colectados en la ribera del arroyo El Parque (Tucumán-Argentina). Una parte fue herborizada y la otra se fijó en FAA. Posteriormente fueron utilizadas técnicas histológicas convencionales y se determinaron la densidad estomática y el tamaño de estomas y tricomas. Se realizaron pruebas histoquímicas para la detección de almidón (lugol) y compuestos fenólicos (cloruro férrico al 10\%).

Resultados clave: Anemia phyllitidis var. phyllitidis muestra raíces diarcas y rizoma dictiostélico cubierto por tricomas glandulares. El pecíolo posee tricomas glandulares, epidermis y subepidermis formada por fibras lignificadas, haz vascular con xilema rodeado por floema, periciclo bistrato rodeado por endodermis y en el tejido cortical almidón y compuestos fenólicos. Las pinnas estériles poseen estomas pericíticos, anomocíticos y desmocíticos (tamaño promedio $49.8 \mu \mathrm{m} \times 38.7 \mu \mathrm{m}$ ); tricomas glandulares; lámina dorsiventral, hipostomática y haces vasculares con periciclo y endodermis. Las pinnas fértiles son anatómicamente semejantes al raquis. Algunas células epidérmicas de los distintos órganos evidenciaron la presencia de sílice.

Conclusiones: El esporofito de $A$. phyllitidis var. phyllitidis mostró rasgos anatómicos, morfológicos y fisiológicos que revelan su adaptación al hábitat ribereño donde crece. Al mismo tiempo, se profundiza la descripción de esta variedad y se aportan datos inéditos del género, como la presencia de estegmata en las pinnas fértiles.

Palabras clave: ambientes xéricos, bosques riparios, estegmata, tricoma, sílice.

${ }^{1}$ Facultad de Ciencias Naturales e Instituto Miguel Lillo (UNT), Miguel Lillo 205, T4000JFE San Miguel de Tucumán, Argentina.

${ }^{2}$ Fundación Miguel Lillo (FML), Miguel Lillo 251, T4000JFE San Miguel de Tucumán, Argentina.

${ }^{3}$ Author for correspondence: mahernandez@lillo.org. ar, albornoz@csnat.unt.edu.ar, plalbornoz@lillo.org.ar
Received: December 5, 2020.

Reviewed: January 18, 2021

Accepted by Rosario Redonda Martínez: March 8, 2021

Published Online first: March 26, 2021.

Published: Acta Botanica Mexicana 128 (2021).

This is an open access article under the Cretive Commons 4.0 Attribution-Non commerBY-NC 4.0 International).
To cite as: Romagnoli, M. G., M. A. Hernández and P. L. Albornoz. 2021. Anatomy of the sporophyte of Anemia phyllitidis var. phyllitidis (Anemiaceae) from a riparian forest (Tucumán, Argentina). Acta Botanica Mexicana 128: e1830. DOI: https://doi.org/10.21829/ abm128.2021.1830

e-ISSN: $2448-7589$ 


\section{Introduction}

Based on phylogenetic studies, Smith et al. (2006) segregated the family Schizaeaceae into three monophyletic families: Anemiaceae, Lygodiaceae and Schizaeaceae. The family Anemiaceae includes a single genus, Anemia Sw., with about 115-120 species (PPG I, 2016; Ramos Giacosa, 2016; Smith and Kessler, 2017). This genus is morphologically characterized by hemidimorphic or dimorphic pinnae, sporangia with continuous subapical annulus, and striated trilete spores (Smith et al., 2006; Labiak et al., 2015, 2018). In Argentina seven species of the genus Anemia are recognized, all characterized by two fertile, erect basal pinnae (Ramos Giacosa, 2016). One of them, Anemia phyllitidis (L.) Sw. presents pinnate laminae, sterile pinnae with a well developed middle nerve that may extend up to the apex, and anastomosing lateral veins. Fertile pinnae show a markedly reduced lamina, on which sporangia are distributed (Labiak et al., 2015). Two varieties are known in Argentina: var. phyllitidis and var. tweediana (Hook.) Hassl., with the former differing from the latter in having fertile pinnae that generally exceed the lamina length and a robust mid nerve that extends to the apex (Ramos Giacosa, 2016).

Anemia phyllitidis is widely distributed from the south of Brazil, Uruguay, and Paraguay, to northeastern and northwestern Argentina. De la Sota (1977) mentions that this species is present in piedmont forests in northwestern Argentina, growing on walls and humid sites. It has frequently been mentioned as a species present in riparian forests and showing tolerance to reduced environmental quality, due to human action and to the edge effects occurring in these environments (Forsthofer and Athayde-Filho, 2012; Miguez et al., 2013; Mallmann and Schmitt, 2014; Mallmann et al., 2016; Graeff et al., 2019; Silva et al., 2019). Water regime in riparian forests is associated with precipitations and seasonal changes; therefore, river flow and water availability vary throughout the year (Granados-Sánchez et al., 2006).

Regarding the anatomical records for the family Schizaeaceae, Ogura (1972) describes diarch roots, rhizome with filiform trichomes, silica crystals in xylem and phloem, and petioles with respiratory line; on the other hand, for most of the species of the genus Anemia this author mentioned a dictyostelic stele in the rhizome. While in $A$. to- mentosa (Sav.) Sw. var. anthriscifolia (Schrad.) Mickel and A. villosa Humb. \& Bonpl. ex Willd., there are records for the lamina and petiole (Ribeiro et al., 2007). Ribeiro Wetzel et al. (2019) determined morphological and anatomical characters to differentiate $A$. villosa, $A$. organensis Rosenst. and their hybrid. Furthermore, Luján et al. (2011) conducted epidermal studies of different groups of medicinal lycophytes and ferns, such as $A$. australis (Mickel) M. Kessler \& A.R. Sm. Ponce (1982) described the morpho-anatomy of $A$. tomentosa var. tomentosa and related it to the environment where it occurs. Moraes Neto (2019) described the anatomy of sterile leaves of six species of Anemia and associates the main adaptive characters with the ecological information of its habitat.

Studies conducted on A. phyllitidis include descriptions of the epidermis structure and ontogeny of stomata (Mickel and Lersten, 1967; Pant and Khare, 1972), whereas for the petiole, the vascular bundle was described as Gleichenia type (Ogura, 1972) and Hernández-Hernández et al. (2012) mentioned the absence of the circumendodermal band. Nevertheless, due to the lack of information on the sporophyte anatomy of Anemia phyllitidis var. phyllitidis, the aim of this work was to characterize this.

\section{Materials and Methods}

\section{Study area}

The specimens of Anemia phyllitidis var. phyllitidis were collected from the riparian forest of the El Parque stream, Yerba Buena department (Tucumán, Argentina) (Fig. 1). The sampling site is located in the Yungas ecoregion; the climate is moderate temperate rainy, with mild dry winter and warm and rainy summer; mean annual temperature ranges between 18 and $20{ }^{\circ} \mathrm{C}$, and annual precipitations between 600-1000 mm (Cwak) (Mendoza and González, 2011). The area includes the headwaters of important basins, with rivers and streams of well-drained rocky substrates exposed to high solar radiation, depending on the vegetation cover (Sirombra and Mesa, 2010).

\section{Study material}

The collected material was identified using the keys of Ramos Giacosa (2016) and deposited in the Pteridological Herbarium (LIL) of the Fundación Miguel Lillo. 


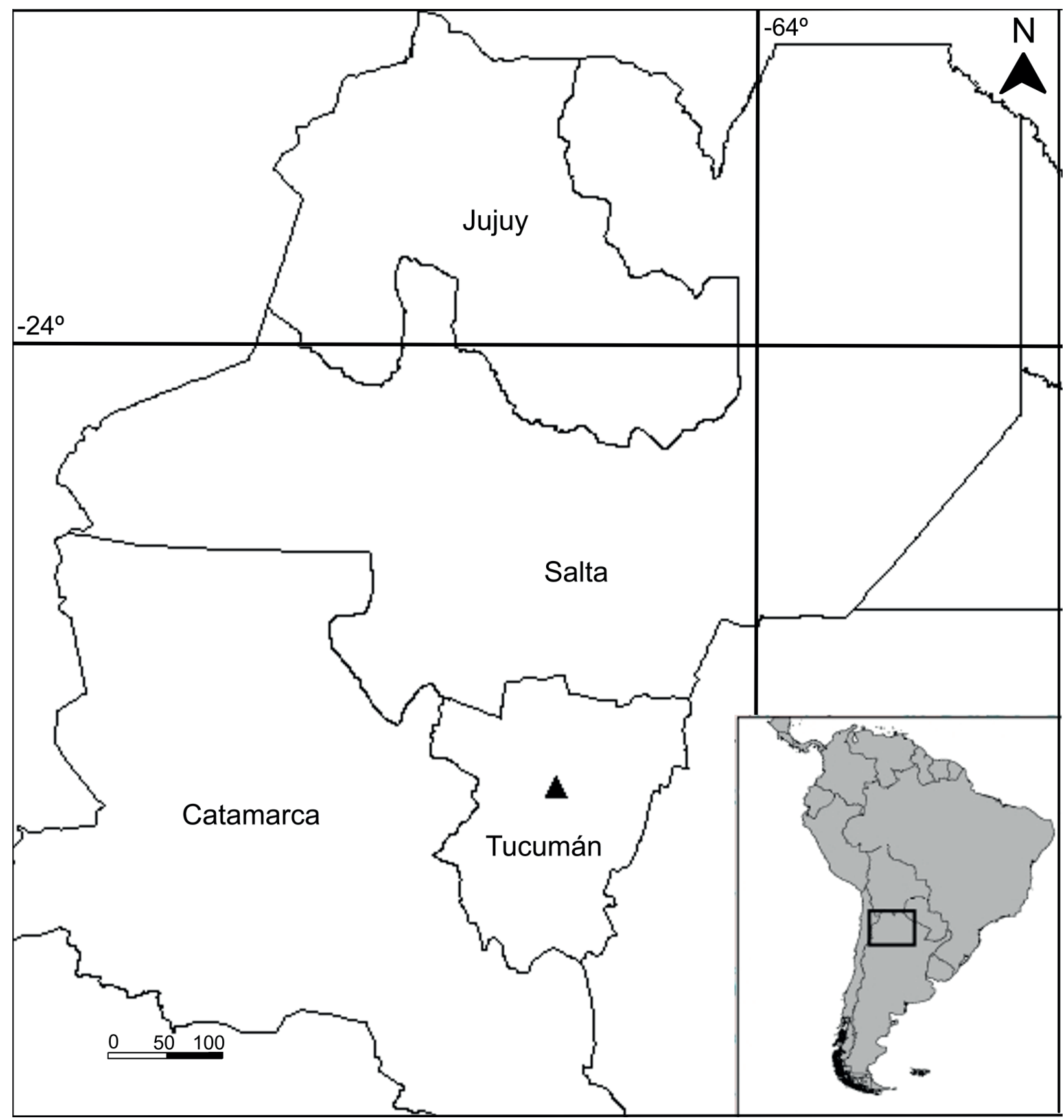

Figure 1: Collection site of Anemia phyllitidis (L.) Sw. var. phyllitidis in El Parque stream, Tucumán, Argentina. The triangle represents the collection locality.

Material examined: ARGENTINA. Tucumán, Yerba Buena department, San Javier, $745 \mathrm{~m}, 26^{\circ} 48^{\prime} 15.44^{\prime \prime S}$ $65^{\circ} 20^{\prime} 30.44^{\prime \prime W}, 17 . I 1.2018$, M. G. Romagnoli et al. 3607 (LIL), 3608 (LIL), 3609 (LIL), 3610 (LIL), 3611 (LIL).

\section{Anatomical analysis}

The anatomical studies were performed on fresh material of five specimens of Anemia phyllitidis var. phyllitidis (Fig. 2A), with five repetitions for each organ in every specimen. A part was herborized and the other part was fixed in FAA (1:1:8 v/v/v formaldehyde: glacial acetic acid: $80 \%$ ethyl alcohol). Leaf and petiole epidermis were cleared for paradermal observations using the technique of Dizeo de Strittmatter (D’Ambrogio de Argüeso, 1986), followed by staining with crystal violet. Free-hand transverse and longitudinal sections of root, rhizome, petiole (basal, middle, and apical), and of the middle portion of rachis and lamina (fertile and sterile) were made. Sections were cleared with commercial 
sodium hypochlorite-water solution (1:1), rinsed five times with distilled water, and then subjected to differential staining with safranin and astra blue (D'Ambrogio de Argüeso, 1986). Transverse sections of the petiole were subjected to histochemical tests to detect starch (lugol solution) and phenols ( $10 \%$ ferric chloride) (D'Ambrogio de Argüeso, 1986). Free-hand transverse sections were prepared for scanning electron microscope (SEM) observations using fresh material of the sterile pinnae. They were cleared with commercial sodium hypochlorite-water solution (1:1), rinsed five times with distilled water, dried with filter paper, and then mounted on aluminium stubs with double-sided carbon tape (Zarlavsky, 2014).

Observations were made with a stereoscopic microscope (Olympus SZX7, Olympus Co., Tokyo, Japan), light microscope (Carl Zeiss, Axiostar Plus, Göttingen, Germany), and polarized light microscope (Carl Zeiss, AXIO Lab. A1, Göttingen, Germany). Chemical identification of cell wall incrustations was performed with SEM Supra 55VP (Carl Zeiss, Oberkochen, Germany) with X-ray analyzer (EDS Inca, Oxford, UK) at the Centro Integral de Microscopía Electrónica (CIME) - Consejo Nacional de Investigación Científica y Técnica (CONICET), Tucumán. Micrographs were taken with a digital camera (Olympus SP350, 8.0MP, Tokyo, Japan).

Types of stomata were determined using the classification of Van Cotthem (1970). Mean, maximum and minimum values, and mean squared error were calculated for the following anatomical characteristics: length and width of stomata, and length of trichomes. Density was calculated for stomata, naviculate and unicellular glandular trichomes in $n=10$ fields of view at $\times 40$ objective lens with five repetitions for each individual ( $n=815$ stomata and $n=325$ trichomes).

\section{Results}

\section{Root}

The primary root has a single-layered epidermis. The cortex is composed of 3-4 layers of outer area of parenchyma cells and 4-5 layers of inner area of lignified sclerenchyma (Figs. 2B, C). In the inner boundary of the cortex, there is an endodermis with Casparian strips, with thickenings in the radial walls. The vascular cylinder has a single-layered pericycle and diarch stele (Fig. 2D).

\section{Rhizome}

The rhizome has a single-layered epidermis with thick lignified walls. The cortex has 8-14 outer layers of non-lignified sclerenchyma; internally, sclerenchyma shows different degrees of lignification. The stele is a dictyostele and is composed of three meristeles, each one of variable size and shape (Fig. 2E). The rhizome surface is densely covered with multicellular uniseriate glandular trichomes (Fig. 2F).

\section{Petiole}

The petioles are dark brown at the base, characterized externally by two lateral respiratory lines at the base of newly emerging and older fronds. These parallel lines are distinguished by darker coloration (Fig. 3A).

In cross section, the basal petiole base is triangular (Fig. 3B), whereas the middle and apical portions are subcircular, with an adaxial deep groove (Figs. 3C, D). This groove extends longitudinally and continues along the rachis.

The petiole has a thick cuticle and a single-layered epidermis composed of thick-walled, lignified fibers, with reduced lumen (Fig. 3E). Some epidermal cells present a refractive conical projection on the outer periclinal wall (Fig. 3F). Stomata and glandular trichomes are on both surfaces. The subepidermal tissue is sclerenchymatous and it is composed of 3-7 layers of lignified fibers; the outer cell layers exhibit more thickened walls than the inner layers. The cortex is parenchymatous and is composed of 13-21 cell layers (Fig. 3C).

The basal and middle regions of the petiole show a single vascular bundle (Figs. 3B, C), whereas in the apical region they present three vascular bundles, the central one being larger and two lateral ones corresponding to leaf traces migrating towards the pinnae (Fig. 3D). The vascular bundles are surrounded by an endodermis with Casparian strips and two-layered pericycle (Fig. 3G). The xylem is open V-shaped (Fig. 3C), and has lignified sclerenchymatous cells at the adaxial side and the ends (Figs. 3G, H), and is surrounded by discontinuous phloem. There are two types of glandular trichomes: 1) long, multicellular, uniseriate, with a terminal gland, similar to those of the rhizome; 2) uni- or bicellular foot and unicellular head, of variable length (Fig. 3I). Because both types of trichomes cover the whole petiole surface, their density was not calculated. Starch grains and phenolic 

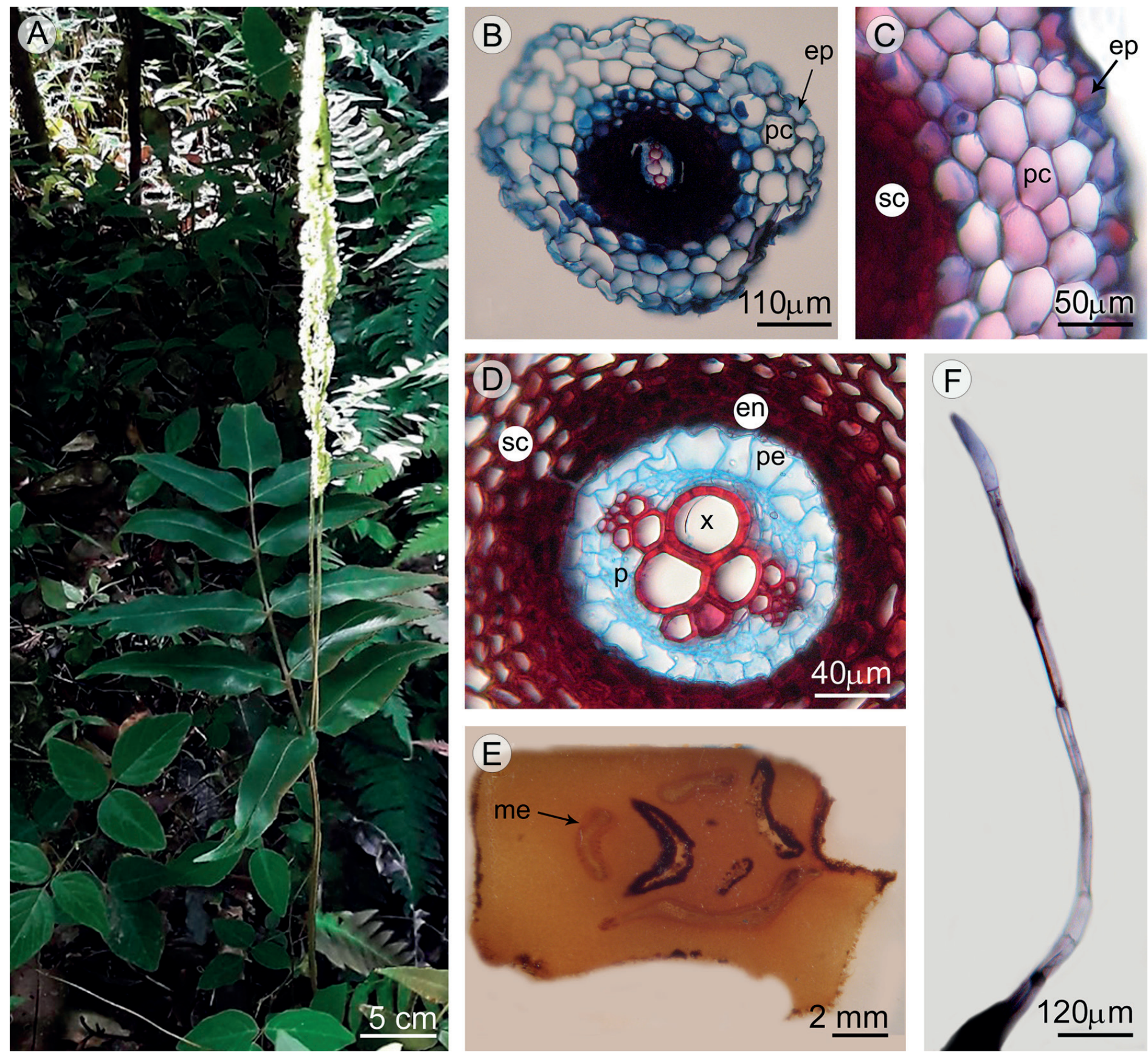

Figure 2: Root and rhizome anatomy of Anemia phyllitidis (L.) Sw. var. phyllitidis. A. appearance of the sporophyte; B-D. root, transverse section; B. appearance of the primary root; C. detail of epidermis and cortex; D. detail of lignified cortex and diarch stele; E. rhizome, transverse section; F. multicellular uniseriate glandular trichome of rhizome. Abbreviations: en=endodermis; $\mathrm{e}=\mathrm{epidermis;}$ me=meristele; $p=p h l o e m ; p c=p a r e n c h y m a t o u s$ cortex; pe=pericycle; sc=sclerenchyma; $x=x y l e m$.

compounds are observed in the cortical parenchyma and in parenchyma associated with vascular tissues (Figs. 3J-L).

In cross section of the basal petiole, the respiratory lines are observed as a lateral interruption of the subepidermal sclerenchyma tissue. A parenchyma with some intercellular spaces is observed in these areas (Figs. 3B, M).

\section{Rachis}

The rachis is semiterete and has a marked groove on the adaxial side. The epidermis is single-layered and has cells with thick lignified walls and reduced lumen. Some epidermal cells show a refractive conical projection on the outer periclinal wall, similar to that described for the petiole. 

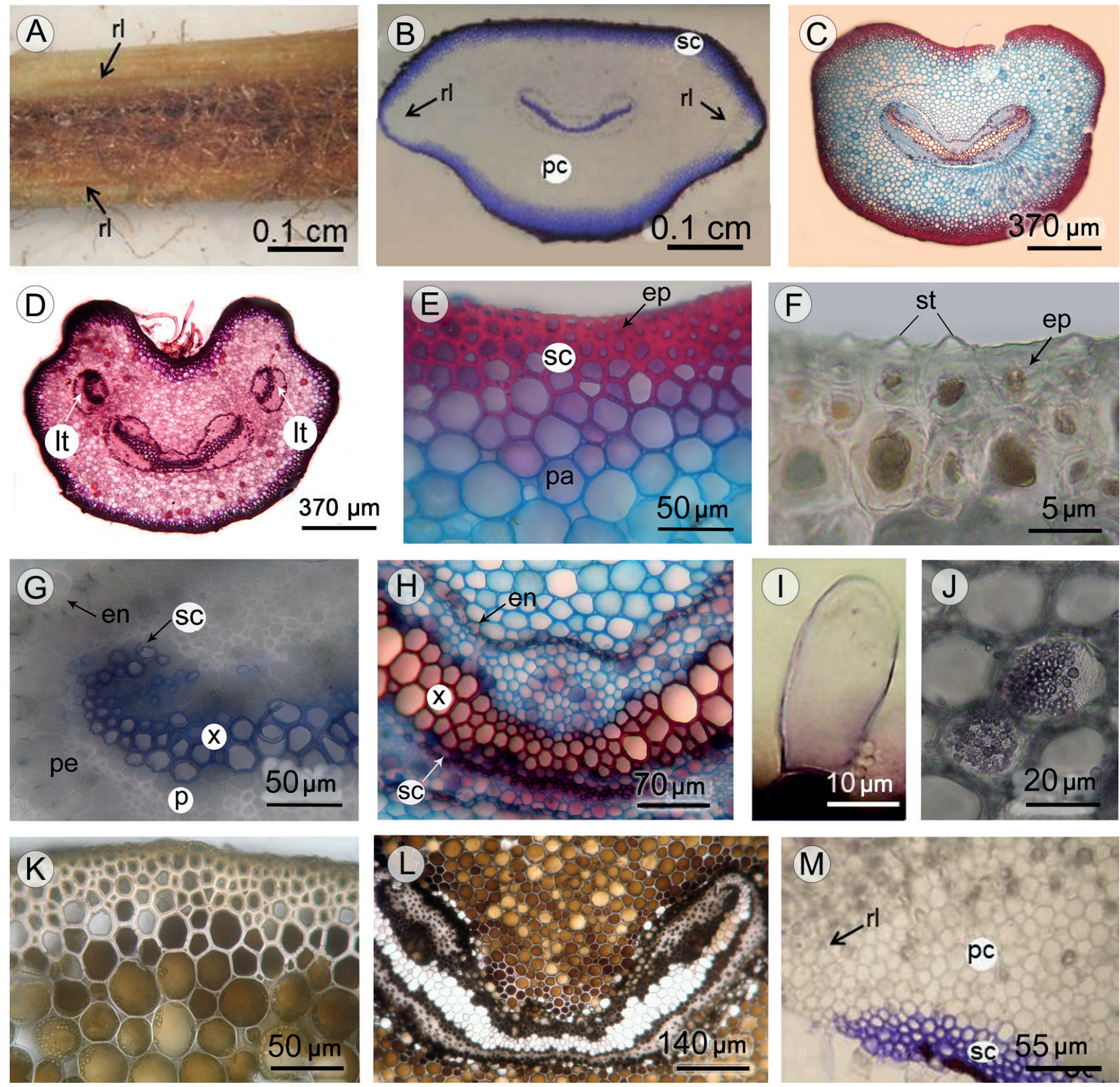

Figure 3: Petiole of Anemia phyllitidis (L.) Sw. var. phyllitidis. A. basal petiole showing two respiratory lines. B-H. cross section; B. basal region with two lateral respiratory lines (arrows); C. middle region; D. apical region; E, F. epidermis with conical stegmata; G, H. vascular bundles; I. uni- or bicellular foot and unicellular head glandular trichome; J. starch grains inside cortical parenchyma cells; K, L. phenolic compounds in parenchyma; M. detail

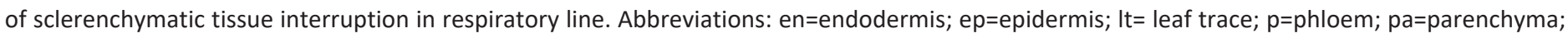
pe=pericycle; $\mathrm{pc}=$ parenchymatous cortex; $\mathrm{rl}=$ =respiratory line; $\mathrm{sc}=$ sclerenchyma; $s t=$ stegmata; $\mathrm{x}=\mathrm{xylem}$.

Multicellular, uniseriate glandular trichomes, comparable to those described for the petiole and rhizome, are observed. Subepidermal tissue is composed of 2-3 layers of lignified sclerenchyma. The cortex is parenchymatous and is composed of 3-11 cell layers. Three vascular bundles were observed; the largest one is in central position. The xylem is surrounded by phloem, endodermis with Casparian strips, and a two-layered pericycle (Fig. 4A). 

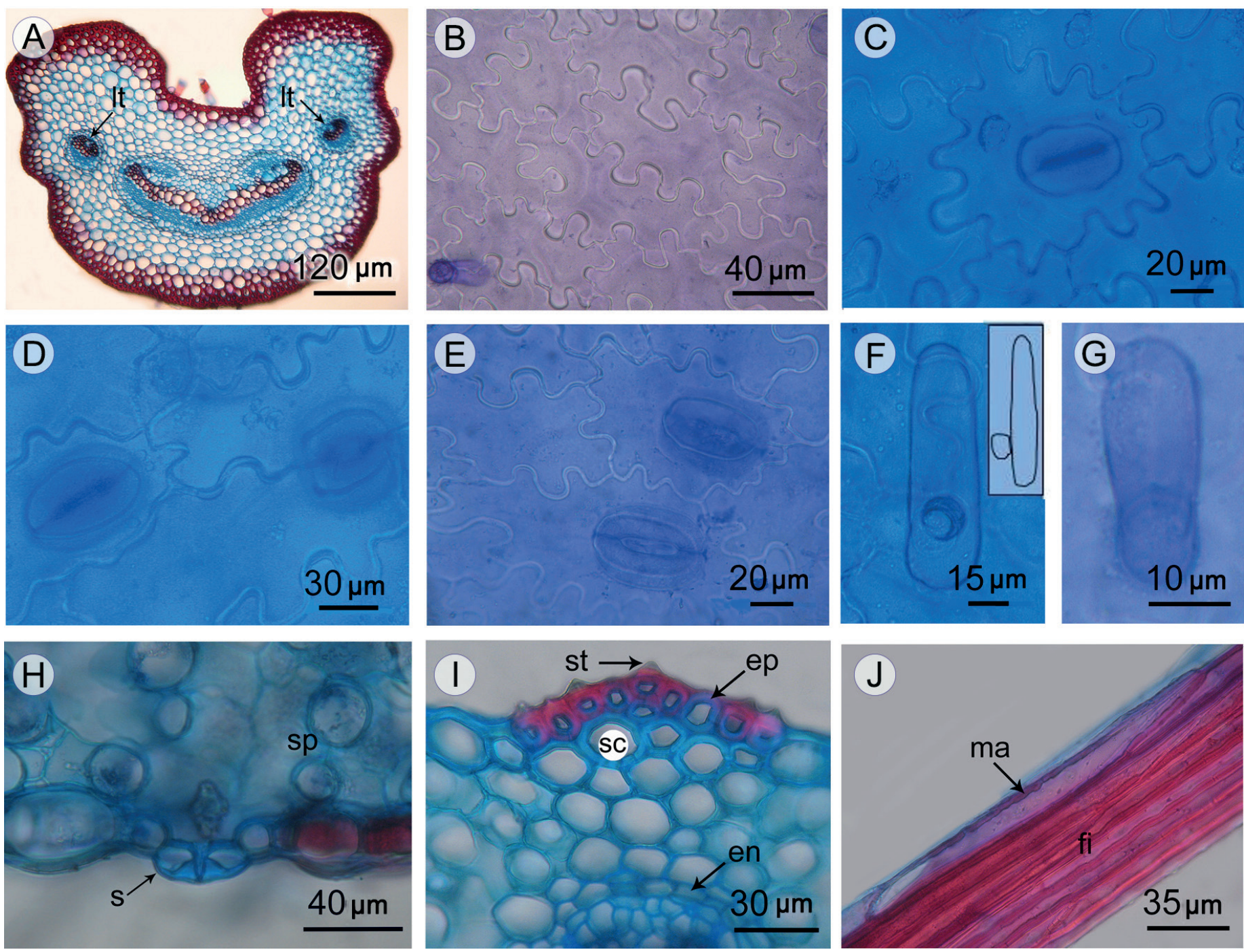

Figure 4: Rachis and sterile pinnae of Anemia phyllitidis (L.) Sw. var. phyllitidis. A. rachis showing two leaf traces (arrows); B. surface view of abaxial epidermis; C. pericytic stomata; D. anomocytic stomata; E. desmocytic stomata; F. naviculate glandular trichome; G. unicellular glandular trichome; $\mathrm{H}$. detail of stomata raised above the epidermal cells; I. transverse section of sterile pinna showing epidermis with conical stegmata and cells with lignified walls; J. sterile pinna, longitudinal section of midvein showing macrosclereids and subepidermal fibers. Abbreviations: en=endodermis;

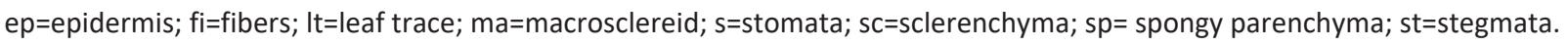

\section{Sterile pinnae}

On surface view, both epidermises exhibit rectangular cells with lobed walls, thick and smooth cuticle (Fig. 4B). The leaf is hypostomatic, stomata are pericytic (97\%), anomocytic (2\%) and desmocytic (1\%) (Figs. 4C-E). Stomata size and density are indicated in Table 1.

Pinnae exhibit three types of glandular trichomes: 1) naviculate (Fig. 4F); 2) single-celled (Fig. 4G), both located on the entire abaxial surface; 3) multicellular uniseriate, composed of 5-7 cells and an elongated terminal gland, identical to those observed in rhizome and petiole, arranged mainly on the middle veins and, to a lesser extent, on the margins of the abaxial side. Length and density of trichomes are shown in Table 1.

Transversally, the lamina is dorsoventral and both epidermises are single-layered. The adaxial surface cells have outer convex periclinal walls, and the guard cells of stomata are at the same level or are raised above the epidermal cells (Fig. $4 \mathrm{H}$ ). Near the veins, on both surfaces, macrosclereids with thickened and, generally, lignified walls, are observed (Figs. 4I, J). Some of these cells have a refractive conical projection on the outer periclinal wall similar to that 
Table 1: Size and density of stomata and trichomes of the sterile pinnae of Anemia phyllitidis (L.) Sw. var. phyllitidis.

\begin{tabular}{lccc}
\hline Characters & $\begin{array}{c}\text { Minimum and } \\
\text { maximum }(\mu \mathrm{m})\end{array}$ & $\begin{array}{c}\text { Mean } \\
(\mu \mathrm{m})\end{array}$ & $\begin{array}{c}\text { Density } \\
\left(\mathrm{mm}^{2}\right)\end{array}$ \\
\hline $\begin{array}{l}\text { Stomata length } \\
\text { Stomata width }\end{array}$ & $30.5-62.5$ & $49.8 \pm 0.1$ & 21 \\
$\begin{array}{l}\text { Length of naviculate } \\
\text { glandular trichomes }\end{array}$ & $75-90$ & $38.7 \pm 0.1$ & \\
$\begin{array}{l}\text { Length of single-celled } \\
\text { glandular trichomes }\end{array}$ & $25-57.5$ & $48.1 \pm 0.2$ & 22 \\
\hline
\end{tabular}

observed on the epidermal cells of the petiole and rachis (Fig. 4I). In the subepidermal position, there are 1-2 layers of fibers (Fig. 4J). The mesophyll is composed of 2-3 layers of palisade parenchyma and 4-5 layers of spongy parenchyma (Fig. 5A). Vascular bundles are collateral, with a sheath of parenchyma cells; xylem and phloem are surrounded by an endodermis with Casparian strips thickened on the radial walls, and a two-layered pericycle (Figs. 5B, C).

\section{Fertile pinnae}

Fertile pinnae have a completely reduced lamina; primary, secondary, and tertiary axes are observed, which are structurally and anatomically identical to the rachis. Transversally, both epidermises are single-layered, composed of cells with thick and lignified walls. They have a conical refractive projection on the outer periclinal wall, similar to those described for other organs. Below the epidermis, there are 1-2 layers of sclerenchyma that can be lignified or not, and 3-6 layers of parenchyma. The central vascular bundle is surrounded by an endodermis with Casparian strips and a two-layered pericycle (Fig. 5D). Multicellular uniseriate glandular trichomes, similar to those described for other organs, are observed on the surface. The sporangia are born on the abaxial margin of the tertiary axes.

\section{X-ray elemental analysis (EDS)}

The X-ray elemental spectrum analysis carried out on the conical projections observed in the outer periclinal walls of sterile pinnae epidermal cells, showed the presence of oxygen (47\%), carbon (33\%) and silica (20\%) at the level of the middle vein (Figs. 5E, F). This finding confirms the pres- ence of silica in these cells and suggests that all the similar structures observed in the different organs have the same chemical composition.

\section{Discussion}

The sporophyte anatomy of $A$. phyllitidis var. phyllitidis showed the presence of epidermal appendages in the petiole, rachis, and lamina, and a well-developed sclerenchyma tissue in roots, rhizomes, petioles, rachis and central veins of lamina. These results agree with records for other species of the genus Anemia (Ribeiro et al., 2007; Ribeiro Wetzel et al., 2019).

The presence of trichomes and sclerenchyma is considered a xeromorphic character because they help to reduce water loss (Hevly, 1963) and have been reported in ferns that grow in xeric environments as was recorded in species of Cheilanthoideae (Hernández et al., 2008, 2011; Dematteis et al., 2019); in epiphytic ferns due to discontinuous water supply (Lagoria et al., 2018), and in eudicots, that grow in environments with an extended dry season period (Bieras, 2006).

The studied variety showed primary roots with diarch stele and dictyostelic rhizomes with uniseriate multicellular glandular trichomes, similar to those of the lamina, petiole and rachis. The petiole exhibited two respiratory lines in the basal portion. These characters are consistent with those reported by Ogura (1972) for the genus; however, the author described filiform trichomes and the presence of silica in the parenchyma cells of the rhizome, xylem and phloem, which were not observed in our material. The respiratory lines in this variety also agree with the findings reported by Ribeiro et al. (2007) for other species of the genus. According to Ogura (1972), these lines might have a respiratory function in diverse fern groups.

Regarding the trichomes of the lamina, we observed three types of glandular trichomes: naviculate, unicellular, called clavate by Roux et al. (1992), and uniseriate multicellular with terminal gland. The latter authors also consider naviculate and clavate trichomes as glandular in species of the genus Mohria Sw., whereas Luján et al. (2011) described unicellular trichomes as eglandular in Anemia australis. The multicellular uniseriate glandular trichome described in this research agrees with the findings of Roux et al. (1992) and Luján et al. (2011). The petiole showed two types of glandular 

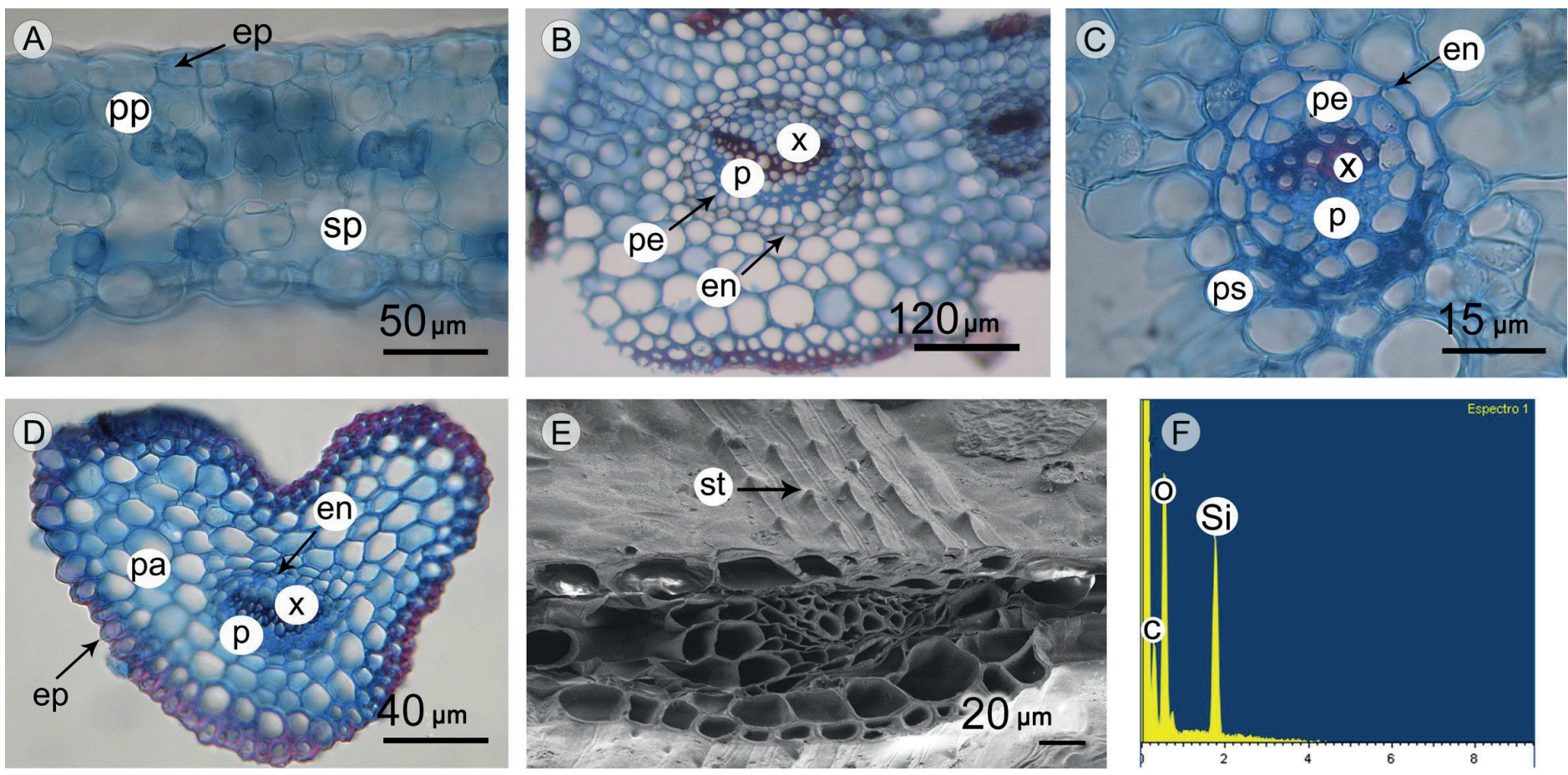

Figure 5: Sterile and fertile pinnae of Anemia phyllitidis (L.) Sw. var. phyllitidis. A-E. transverse section. A-C, E, F. sterile pinnae; A. palisade and spongy parenchyma; B. detail of main vein; C. secondary vascular bundle; D. fertile pinnae; E. appearance of stegmata; F. X-ray spectrum of stegmata; $E$,

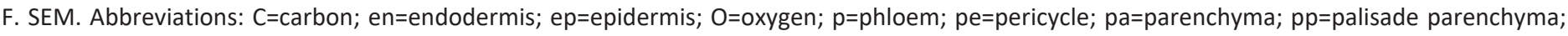

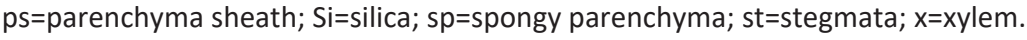

trichomes: unicellular to bicellular foot with unicellular head, and uniseriate multicellular with terminal gland. Ribeiro et al. (2007) mentioned uniseriate and glandular trichomes in the petiole of $A$. tomentosa and $A$. villosa; however, their description is insufficient, and no images are provided.

The types of stomata reported by Tryon and Tryon (1982) for the genus Anemia are pericytic and desmocytic. In the variety here studied we observed desmocytic, anomocytic and pericytic, the latter being most abundant. This finding agrees with results reported by Mickel and Lersten (1967) and Pant and Khare (1972). However, we did not observe the anisocytic and paracytic types mentioned by the latter authors. This disagreement is related to the fact that these types of stomata are scarce, representing less than $2 \%$ of the total number found by those authors. The low stomata density (21 per $\mathrm{mm}^{2}$ ) recorded for A. phyllitidis var. phyllitidis agrees with that described by Pant and Khare (1972) for the species. This variable decreases under stress conditions, such as drought and high solar radiation, to avoid an excess of transpiration (Cañizares et al., 2003; Gabriel y Galán et al., 2011).

The presence of starch and phenolic compounds in cortical parenchyma and in parenchyma associated with vascular tissues of the petiole is consistent with the findings of Ribeiro et al. (2007) for A. tomentosa var. anthriscifolia and A. villosa. During the desiccation process, starch is converted into soluble sugars, and plays a fundamental role in cell protection against mechanical damage due to water deficit (Cushman and Oliver, 2011; Banupriya et al., 2020). Phenolic compounds were mentioned as a common characteristic in ferns (Ogura, 1972). These compounds act as a defense mechanism against herbivory, insect attack (Mehltreter, 2010), and as a protection mechanism of cells against photo-oxidative stress occurring during water scarcity and high solar radiation (Bartels and Hussain, 2011; Acuña Contreras, 2015; John, 2017).

Silica is associated with plant resistance to desiccation and herbivory, it maintains rigidity of stems and leaves, and 
contributes to defense against microorganisms and fungi (Ramussen, 1986; Prychid et al., 2004; Ma and Yamaji, 2006; Ribeiro et al., 2007; Nawaz et al., 2019). Silica in plant cells can be found as translucent deposits in the cell lumen, known as silica bodies or as silica impregnations on the wall of the epidermal cells (Sandoval, 2005); the latter was observed in the material here studied. The refractive conical silica projections observed in the outer periclinal walls of the epidermis of petiole, rachis, and sterile and fertile pinnae of Anemia phyllitidis var. phyllitidis are similar to stegmata. According to Prychid et al. (2004), this term was coined by Mettenius in 1864 for ferns, referring to the silica bodies associated to the sclerenchymatic tissue next to vascular bundles, whereas Tomlinson (1969) named epidermic stegmata the cells that contain silica in the costal epidermis in monocots. The presence of silica crystals in the outer walls of some epidermal cells of the lamina in Anemia was reported by Ogura (1972) as a common characteristic of the genus; however, it is not described for the fertile pinnae. Furthermore, silica was also mentioned for other species of the order Schizaeales such as Lygodium japonicum (Thunb.) Sw. (Ma and Takahashi, 2002) and L. flexuosum (L.) Sw. (Chauhan et al., 2009). In this research we call these silica impregnations stegmata in agreement with Ribeiro et al. (2007) and Ribeiro Wetzel et al. (2019) who observed them in A. tomentosa var. anthriscifolia, $A$. villosa and $A$. organensis.

Riparian ferns, along with other species, are affected by the increase of seasonal ecological pressures, such as low humidity, higher light intensity and increased temperature (Granados-Sánchez et al., 2006; Graeff et al., 2019). Anemia phyllitidis occurs in riparian forests, on well-drained rocky substrate exposed to sun radiation and where water availability varies seasonally (Tryon and Tryon, 1982; Granados-Sánchez et al., 2006; Mallmann and Schmitt, 2014; Padoin et al., 2015). Carvajal-Hernández and Krömer (2015) and Proctor and Tuba (2002) mentioned this species is tolerant to abiotic factors such as drought, high temperatures and high light intensity.

\section{Conclusions}

The sporophyte of $A$. phyllitidis var. phyllitidis showed anatomical, morphological and physiological traits that reveal its adaptation to the riparian habitat where it grows: epidermal appendages and abundant sclerenchyma tissue in different organs, low stomatal density, silica in epidermal cells, phenolic compounds, and starch. At the same time, the description of this variety is deepened and unpublished data for the genus are provided, such as the presence of stegmata in the fertile pinnae.

\section{Author contributions}

MGR, MAH and PLA designed the present research and collected the material. MGR applied the conventional histological techniques and acquired the data. MGR and PLA conducted the anatomical interpretation. All the authors contributed to discussion, revision and approval of the manuscript.

\section{Funding}

This research received financial support from Fundación Miguel Lillo, projects B-0030-1 and B-0002-1.

\section{Acknowledgements}

To the Fundación Miguel Lillo (FML) for providing the physical space and equipment, which allowed us to conduct this study. Lelia Bordón, from the Iconografía section (FML) performed the figures. Guillermo Terán for the elaboration of the map of the study area.

\section{Literature cited}

Acuña Contreras, K. I. 2015. Estrés oxidativo, capacidad antioxidante y contenidos de antioxidantes no enzimáticos en dos Hymenophyllaceae Link. (Pteridophyta) sometidas a un ciclo de desecación y rehidratación bajo intensidades lumínicas distintas. Tesis de doctorado. Facultad de Ciencias Naturales y Oceanográficas. Universidad de Concepción. Concepción, Chile. 116 pp.

Banupriya, T. G., C. Ramyashree, D. Akash, N. S. Yathish and R. G. Sharthchandra. 2020. Studies on the mechanism of desiccation tolerance in the resurrection fern Adiantum raddianum. Journal of Applied Biology and Biotechnology 8(1): 6-14. DOI: https://doi.org/10.7324/JABB.2020.80102

Bartels, D. and S. S. Hussain. 2011. Resurrection Plants: Physiology and Molecular Biology. In: Lüttge, U., E. Beck and D. Bartels (eds.). Plant Desiccation Tolerance. Ecological Studies (Analysis and Synthesis), vol. 215. Springer. Berlin, Germany. Pp: 339364. DOI: https://doi.org/10.1007/978-3-642-19106-0_16 
Bieras, A. C. 2006. Morfologia e anatomia foliar de dicotiledôneas arbóreo-arbustivas do cerrado de São Paulo, Brasil. Tese doutorado. Instituto de Biociencias, Universidade Estadual Paulista. São Paulo, Brasil. 67 pp.

Cañizares, A., M. E. Sanabria, D. Rodríguez and Y. Perozo. 2003. Características de los estomas, índice y densidad estomática de las hojas de lima Tahití (Citrus latifolia Tanaka) injertada sobre ocho patrones cítricos. Revista Científica UDO Agrícola 3(1): 59-64.

Carvajal-Hernández, C. I. and T. Krömer. 2015. Riqueza y distribución de helechos y licófitos en el gradiente altitudinal del Cofre de Perote, centro de Veracruz, México. Botanical Sciences 93(3): 601-614. DOI: https://doi.org/10.17129/ botsci.165

Chauhan, D. K., D. K. Tripathi, P. Sinha and S. P. Tiwari. 2009. Biogenic silica in some pteridophytes. Bionature 29: 1-9.

Cushman, J. C. and M. J. Oliver. 2011. Understanding vegetative desiccation tolerance using integrated functional genomics approaches within a comparative evolutionary framework. In: Lüttge, U., E. Beck. and D. Bartels (eds.). Plant Desiccation Tolerance. Ecological Studies (Analysis and Synthesis), vol. 215. Springer. Berlin, Germany. Pp. 307-338. DOI: https://doi.org/10.1007/978-3-642-19106-0_15

D’Ambrogio de Argüeso, A. 1986. Manual de Técnicas en Histología Vegetal. Ed. Hemisferio Sur. Buenos Aires, Argentina. 84 pp.

De la Sota, E. R. 1977. Pteridophyta. In: Cabrera, A. L. (ed.). Flora de la provincia de Jujuy, República Argentina, parte 2, colección científica del Instituto Nacional de Tecnología Agropecuaria (INTA). Buenos Aires, Argentina. 275 pp.

Dematteis, B., M. S. Solís, J. C. Yesilyurt and E. I. M. Torres. 2019. Anatomía comparada en cuatro helechos Cheilantoideos. Boletín de la Sociedad Argentina de Botánica 54(2): 203-214. DOI: https://doi.org/10.31055/1851.2372.v54.n2.24365

Forsthofer, M. and F. P. Athayde-Filho. 2012. Florística e aspectos ecológicos de samambaias e licófitas ao longo do córrego cachoeirinha, Nova Xavantina-MT. Botánica 63: 149-164.

Gabriel y Galán, J. M., C. Prada, C. H. Rolleri, R. Lahoz-Beltrá and C. Martínez-Calvo. 2011. Biometry of stomata in Blechnum species (Blechnaceae) with some taxonomic and ecological implications for the ferns. Biología Tropical 59(1): 403-415. DOI: https://doi.org/10.15517/rbt.v59i1.3208

Graeff, V., V. L. da Silva, I. T. Mallmann and J. L. Schmitt. 2019. Ferns and lycophytes as a tool to evaluate environmen- tal dissimilarity in riparian forests in southern Brazil. Brazilian Journal of Botany 42(3): 467-476. DOI: https://doi. org/10.1007/s40415-019-00540-3

Granados-Sánchez, D., M. A. Hernández-García and G. F. LópezRíos. 2006. Ecología de las zonas ribereñas. Chapingo, Serie Ciencias Forestales y del Ambiente 12(1): 55-69.

Hernández, M. A., P. L. Albornoz, F. Rodríguez and S. Serrano. 2008. Anatomía de rizoma, raíz y micorrizas arbusculares en Cheilanthes pruinata Kaulf. y C. myriophylla Desv. (Pteridaceae) en el Noroeste Argentino. Lilloa 45(1-2): 73-82.

Hernández, M. A., O. Varela, Y. E. Fernández and M. G. Nadra. 2011. Caracterización morfológica y anatómica del esporofito de Trachypteris pinnata (Pteridaceae) en relación con la xeromorfía. Lilloa 48(2): 153-165.

Hernández-Hernández, V., T. Terrazas, K. Mehltreter and G. Angeles. 2012. Studies of petiolar anatomy in ferns: structural diversity and systematic significance of the circumendodermal band. Botanical Journal of the Linnean Society 169(4): 596-610. DOI: https://doi.org/10.1111/ j.1095-8339.2012.01236.x

Hevly, R. H. 1963. Adaptations of Cheilanthoid ferns to desert environments. Journal of the Arizona Academy of Science 2(4): 164-175. DOI: https://doi.org/10.2307/40026172

John, S. P. 2017. Drying without dying: the resurrection fern Pleopeltis polypodioides. Doctoral dissertation. University of Louisiana at Lafayette. Lafayette, USA. 237 pp.

Labiak, P. H., J. T. Mickel and J. G. Hanks. 2015. Molecular phylogeny and character evolution of Anemiaceae (Schizaeales). Taxon 64(6): 1141-1158. DOI: https://doi.org/10.12705/646.3

Labiak, P. H., J. T. Mickel and F. B. Matos. 2018. Anemia paripinnata (Anemiaceae), a new species from central Brazil. American Fern Journal 108(1): 1-7. DOI: https://doi. org/10.1640/0002-8444-108.1.1

Lagoria, M. A., G. Avila, D. A. Neira, A. M. Rodríguez, N. F. Ríos, J. Prado and M. A. Hernández. 2018. Morphoanatomical and histochemical characteristics of the epiphytic fern Pleopeltis macrocarpa (Polypodiaceae). Brazilian Journal of Botany 41(3): 739-750. DOI: https://doi.org/10.1007/s40415-018-0474-8

Luján, M. C., R. Morero and G. E. Barboza. 2011. Estudios epidérmicos en helechos y licófitas medicinales de la Provincia de Córdoba, Argentina. Hoehnea 38(4): 609-659. DOI: https:// doi.org/10.1590/S2236-89062011000400007 
Ma, J. F. and E. Takahashi. 2002. Soil, fertilizer, and silicon research in Japan. Elsevier. Amsterdam, Netherlands. 281 pp. DOI: https:// doi.org/10.1016/B978-0-444-51166-9.X5000-3

Ma, J. F. and N. Yamaji. 2006. Silicon uptake and accumulation in higher plants. Trends in Plant Science 11(8): 392-397. DOI: https://doi.org/10.1016/j.tplants.2006.06.007

Mallmann, I. T. and J. L. Schmitt. 2014. Riqueza e composição florística da comunidade de samambaias na mata ciliar do Rio Cadeia, Rio Grande do Sul, Brasil. Ciencia Florestal 24(1): 97-109. DOI: https://doi.org/10.5902/1980509813327

Mallmann, I. T., V. L. da Silva and J. L. Schmitt. 2016. Estrutura comunitária de samambaias em mata ciliar: avaliação em gradiente de antropização. Ambiente and Água 11(1): 110-124. DOI: https://doi.org/10.4136/ambi-agua.1717

Mehltreter, K. 2010. Fern conservation. In: Mehltreter, K., L. R. Walker and J. M. Sharpe (eds.). Fern ecology. Cambridge University Press. Cambridge, UK. Pp. 323-359. DOI: https://doi. org/10.1017/СВ09780511844898.010

Mendoza, E. A. and J. A. González. 2011. Las ecorregiones del noroeste argentino basadas en la clasificación climática de Köppen. Series Conservación de la Naturaleza 19: 3-41.

Mickel, J. T. and N. R. Lersten. 1967. Floating stomates (adetostomy) in ferns: distribution and ontogeny. American Journal of Botany 54(9): 1181-1185. DOI: https://doi. org/10.1002/j.1537-2197.1967.tb10751.x

Miguez, F. A., C. Kreutz and F. P. Athayde-Filho. 2013. Samambaias e licófitas em quatro matas de galeria do município de Nova Xavantina, Mato Grosso, Brasil. Pesquisas, Botânica 64: 243-258.

Moraes Neto, P. G. D. 2019. Aspectos estruturais e histoquímicos de Anemia Sw. (Anemiaceae). Tese de mestrado. Universidade Federal Rural da Amazônia. Belém, Brasil. 61 pp.

Nawaz, M. A., A. M. Zakharenko, I. V. Zemchenko, M. S. Haider, M. A. Ali, M. Imtiaz, G. Chung, A. Tsatsakis, S. Sun and K. S. Golokhvast. 2019. Phytolith formation in plants: from soil to cell. Plants 8(8): 249. DOI: https://doi.org/10.3390/plants8080249

Ogura, Y. 1972. Comparative anatomy of vegetative organs of the Pteridophytes. 2nd ed. Gebrüder Borntraeger. Stuttgart, Germany. 502 pp.

Padoin, T. O. H., V. Graeff, V. L. da Silva and J. L. Schmitt. 2015. Florística e aspectos ecológicos das samambaias e licófitas da mata ciliar de um afluente do Rio Rolante no Sul Do Brasil. Pesquisas, Botânica 68: 335-348.
Pant, D. D. and P. K. Khare. 1972. Epidermal structure and stomatal ontogeny of Anemia spp. Annals of Botany 36(4): 809-821. DOI: https://doi.org/10.1093/oxfordjournals.aob.a084637

Ponce, M. M. 1982. Morfología ecológica comparada de las filicopsidas de las sierras Australes de Buenos Aires (República Argentina). Boletín de la Sociedad Argentina de Botánica 21(1-4): $187-211$.

PPG I. 2016. A community-derived classification for extant lycophytes and ferns. Journal of Systematics and Evolution 54(6): 563-603. DOI: https://doi.org/10.1111/jse.12229

Prychid, C. J., P. J. Rudall and M. Gregory. 2004. Systematics and biology of silica bodies in monocotyledons. The Botanical Review 69(4): 377-440. DOI: https://doi.org/10.1663/0006-8101(200 4)069[0377:SABOSB]2.0.CO;2

Proctor, M. C. and Z. Tuba. 2002. Poikilohydry and homoihydry: antithesis or spectrum of possibilities? New Phytologist 156(3): 327-349. DOI: https://doi.org/10.1046/j.14698137.2002.00526.x

Ramos Giacosa, J. P. 2016. Anemiaceae. In: Zuloaga, F. O. and M. J. Belgrano (eds.). Flora Vascular de la República Argentina, Vol. 2: Licofitas, Helechos y Gymnospermae. Estudio Sigma. Buenos Aires, Argentina. Pp. 47-52.

Rasmussen, H. 1986. An aspect of orchid anatomy and adaptationism. Lindleyana 1: 102-107.

Ribeiro, M. L. R., M. Guerra Santos and M. Gomes Moraes. 2007. Leaf anatomy of two Anemia Sw. species (Schizaeaceae-Pteridophyte) from a rocky outcrop in Niterói, Rio de Janeiro, Brazil. Brazilian Journal of Botany 30(4): 695-702. DOI: https://doi. org/10.1590/S0100-84042007000400014

Ribeiro Wetzel, M. L., M. Guerra Santos, C. F. Barros Barros and C. Gonçalves Costa. 2019. Leaf anatomy of two fern species and a hybrid of Anemia (Anemiaceae). American Fern Journal 109(1): 44-53. DOI: https://doi.org/10.1640/0002-8444-109.1.44

Roux, J. P., J. J. A. van der Walt and R. B. van der Merwe. 1992. Systematic studies in the genus Mohria (Pteridophyta: Anemiaceae) I. Comparative morphology and anatomy of the rhizome and frond. South African Journal of Botany 58(2): 83-89. DOI: https://doi.org/10.1016/S0254-6299(16)30876-6

Sandoval, E. 2005. Técnicas aplicadas al estudio de la anatomía vegetal. Cuadernos del Instituto de Biología núm. 38. Universidad Nacional Autónoma de México. México, D.F., México. 281 pp.

Silva, V. L., C. R. Orlandi, L. Funck, M. C. Winhelmann, J. L. Schmitt, C. S. Fior and E. M. Freitas. 2020. Heterogeneity of fern com- 
munities in riparian forest remnants from the South Brazilian Campos (Pampa). Brazilian Journal of Biology 80(4): 803-813. DOI: https://doi.org/10.1590/1519-6984.221124

Sirombra, M. G. and L. M. Mesa. 2010. Composición florística y distribución de los bosques ribereños subtropicales andinos del Río Lules, Tucumán, Argentina. Revista de Biología Tropical 58(1): 499-510. DOI: https://doi.org/10.15517/rbt.v58i1.5224

Smith, A. R. and M. Kessler. 2017. Prodromus of a fern flora for Bolivia. XIII. Anemiaceae. Phytotaxa 329(1): 80-86. DOI: https:// doi.org/10.11646/phytotaxa.329.1.5

Smith, A. R., K. M. Pryer, E. Schuettpelz, P. Korall, H. Schneider and P. G. Wolf. 2006. A classification for extant ferns. Taxon 55(3): 705-731. DOI: https://doi.org/10.2307/25065646
Tomlinson, P. B. 1969. Anatomy of the Monocotyledons. III. Commelinales-Zingiberales. Clarendon Press. Oxford University. Oxford, UK. 466 pp.

Tryon, R. M. and A. F. Tryon. 1982. Ferns and allied plants with special reference to Tropical America. Springer Verlag. New York, USA. 662 pp.

Van Cotthem, W. 1970. Comparative morphological study of the stomata in the Filicopsida. Bulletin du Jardin Botanique National de Belgique 40(2): 81-239. DOI: https://doi. org/10.2307/3667713

Zarlavsky, G. E. 2014. Histología vegetal: Técnicas simples y complejas. Sociedad Argentina de Botánica. Buenos Aires, Argentina. $118 \mathrm{pp}$. 